\title{
Passive cooling for thermal comfort in informal housing
}

\author{
David Kimemia ${ }^{1,2^{*}}$, Ashley Van Niekerk ${ }^{1,2}$, Harold Annegarn ${ }^{3}$, Mohamed Seedat $^{1,2}$ \\ 1 Violence Injury and Peace Research Unit, South African Medical Research Council, P.O. Box 19070, Tygerberg \\ 7505, South Africa. \\ 2 Institute for Social and Health Sciences, University of South Africa, P.O. Box 1087, Lenasia 1820, South Africa. \\ ${ }^{3}$ School of Geo and Spatial Sciences, North-West University, Private Bag X6001, Potchefstroom 2520, South Africa.
}

\begin{abstract}
Energy-poor households in Africa's burgeoning urban informal settlements are especially likely to suffer from heatwaves because of thermally inefficient dwellings and lack of affordable cooling options. This study utilised a controlled experiment to assess the effectiveness of passive cooling through specially formulated paints (cool coatings) in standard informal structures. The test structures were built to simulate typical shack dwellings in South Africa's urban informal settlements. Results showed that the mean daily maximum temperatures of the coated structure were up to $4.3^{\circ} \mathrm{C}$ lower than those in the uncoated structure. The same cooling trend was observed for the minimum daily temperatures, which were lower by an average of $2.2^{\circ} \mathrm{C}$. Besides, the annual frequency of maximum temperature exceedances beyond the critical heat stroke value of $40{ }^{\circ} \mathrm{C}$ dropped from $19 \%$ for the uncoated structure to $1 \%$ for the coated structure. These temperature differences were found to be statistically and subjectively significant, implying that cool coatings may be effective in promoting thermal comfort and climate resilience in poor urban communities. It is recommended that governmental authorities and relevant role players invest in the production and assisted application of cool coatings in urban informal settlements. The interventions promise hope of reduced energy burden on poor households and could be implemented in parallel with ongoing efforts focused on the design and implementation of low-cost, durable and thermally comfortable houses for indigent communities. Ultimately, the endeavours could be a potential policy change to assist in expanding poor households' access to alternative and green energy resources.
\end{abstract}

Keywords: cool coatings; extreme temperatures; informal settlements

\section{Highlights}

- Energy-poor shack dwellers are frequently exposed to elevated summertime heat.

- Passive cooling technologies are perhaps one economically viable option.

- Experimental shacks coated with cool coatings showed lower indoor heat.

- Cool coatings intervention can greatly improve survivability of shack dwellings.

\footnotetext{
Journal of Energy in Southern Africa 31(1): 28-39

DOI: https://dx.doi.org/10.17159/2413-3051/2020/v31i1a7689

Published by the Energy Research Centre, University of Cape Town ISSN: 2413-3051

This work is licensed under a Creative Commons Attribution-ShareAlike 4.0 International Licence

https://journals.assaf.org.za/jesa

Sponsored by the Department of Science and Technology

* Corresponding author: Tel:+27 11670 9616:

email:dkimemia@gmail.com
} 


\section{Introduction}

Global warming is highlighted as a key challenge in the Anthropocene and is associated with higher temperatures and frequent extreme heat events (Intergovernmental Panel on Climate Change, 2014). Exposure to extreme heat is a serious public health concern and one of the major contributors to weather-related mortality (Riley et al., 2018; Garland et al., 2015). Studies indicated that most heatwave deaths occur at home (Madrigano et al., 2015; Alam et al., 2016) with urban populations being more at risk because of compounded effect of the well-documented urban heat island phenomenon (Habeeb et al., 2015).

Developing countries in Africa, Asia and Latin America face the most significant health effects of global warming (World Health Organization (WHO), 2018). In these countries, the most impoverished populations are most at risk for adverse health outcomes related to extreme heat events caused by living in thermally inefficient houses that lack air conditioning (Habeeb et al., 2015). It is estimated that one billion people currently live in informal settlements, mostly in Global South cities, with a projection that about three billion people will be in such settlements by 2030 (United Nations (UN)-Habitat, 2018). As such, the vulnerability of the population is huge and growing.

In much of the Global South, urbanisation has long outstripped local governments' capacities, as evidenced by the high numbers of people living in the informal settlements and service backlogs (Satterthwaite, 2011). Sustainable solutions for these cities should factor in their unique contexts and not just rely on Global North simulations (Muringathuparambila et al., 2017). This is especially so in the urban energy planning of emerging, densely settled African municipalities such as in Gauteng province, South Africa (Madlener \& Sunak, 2011). Understanding this unique set of developmental requirements is key to the attainment of United Nations Sustainable Development Goal (SDG) 7 that aims for universal access to sustainable and modern energy for all and SDG 11 for inclusive, safe, resilient and sustainable human settlements (United Nations, 2019).

Studies have shown that fuel poverty in summer is potentially greater than in other seasons, even in temperate climates (Simoes et al., 2016; Thomson et al., 2019). Cooling needs were neglected in most energy access programmes across the world, with many energisation projects tailored to meet cooking, heating and lighting services (Thomson et al., 2019). However, lack of essential indoor cooling is increasingly viewed as a key dimension of energy injustice that energy planning should consider and solve (Mastrucci et al., 2019).
Energy poverty alleviation and climate change mitigation are largely interlinked challenges, yet they remain disconnected in research and practice (Urge-Vorsatz \& Herrero, 2012). This study took a concurrent view of both challenges by highlighting the health and safety implications of exposure to extreme heat and the disproportionate risk borne by energy-poor households. In addition, the study tested a passive means of cooling low-income informal houses (shacks) through cool coating technology, i.e., highly reflective paints.

Populations of South Africa's shack dwellings, estimated at two million households in 2016, are on the rise (StatsSA, 2018). Informality is perceived to persist in the foreseeable future (Turok \& Borel-Saladin, 2016). As providing formal thermally comfortable housing for entire populations is a long-term aspiration, passive cooling of the current stock of informal structures would render them more habitable and possibly provide a cost-effective mechanism to alleviate some of the worst public health effects of extreme indoor temperatures.

Illnesses attributed to prolonged exposure to high temperatures include heat cramps, heat syncope, heat exhaustion, heat stroke, and death (Harmon, 2010). Of these, heat exhaustion is the most common, and the symptoms include intense thirst, heavy sweating, weakness, paleness, discomfort, anxiety, dizziness, fatigue, fainting, nausea or vomiting, and headache (Lugo-Amador et al., 2004). If untreated, these symptoms may progress to a heat stroke, which is a life-threatening health condition requiring neurocritical care (Hifumi et al., 2018). Heat stroke is clinically defined as a core body temperature $\geq 40{ }^{\circ} \mathrm{C}$, accompanied by hot, dry skin and central nervous system abnormalities such as delirium, convulsions, or coma (Luber \& McGeehin, 2008). Those at the highest risk of heat stress include the elderly and young children (Kovats \& Hajat, 2008).

Heat stress mortality is likely to increase if global warming continues at the same trajectory. Analysis done in India indicated that an increase of about $0.5^{\circ} \mathrm{C}$ between 1960 and 2009 corresponded to an approximate $150 \%$ increase in the probability of heat-related mortality (Mazdiyasni et al., 2017). Projections indicated that African continent will equally experience high increases in heat vulnerability because of increasing maximum apparent temperatures amidst widespread poverty and inequality (Garland et al., 2015; Wright et al., 2019). Contrary to assertions that humans would adapt to any possible warming, evidence indicates that heat stress imposes a robust upper limit to such adaptation, especially if peak heat stress exceeds $35^{\circ} \mathrm{C}$ for long periods (Sherwood \& Huber, 2010). Although several factors may cause heat-related illnesses, an 
elevated environmental heat burden presents the most substantial risk (Ishimine, 2018).

Apart from direct health impacts, elevated ambient temperatures have been linked to a resurgence of residual malaria infections in parts of the Global South (Durnez et al., 2013). These infections occur as people in endemic areas sleep outdoors because their houses are too warm at night (Monroe et al., 2015). The use of cool coatings in such situations may allow people to get indoors by night, thereby reducing exposure to malaria vectors.

In addition, heatwaves were associated with high levels of trauma, chronic stress, anxiety, depressive disorder, suicide and neuropsychiatric syndromes (Doherty \& Clayton, 2011). Further, a relationship between heat and direct violence was reported, with increased global temperatures associated with increasing rates of assault, rape and robbery (Ranson, 2014). A South African study reported higher levels of interpersonal violence during periods of high temperatures and estimated that the current number of homicides in the country may increase by about $5 \%$ with $1{ }^{\circ} \mathrm{C}$ rise in temperature (Chersich et al., 2019). Furthermore, the associations between heat and violence seem notably stronger in disadvantaged communities (Mares \& Moffett, 2016). It is argued that the provision of cooling mechanisms, such as cool coatings, may be a practical way of reducing the 'felt effects' of extreme heat and the associated aggressive behaviours in vulnerable communities (Chersich et al., 2019; Diamond, 2017).

Cool coatings are specially formulated paints with high solar reflectance and infrared emittance (Akbari \& Mathews, 2012). They are used for passive cooling in buildings and work by reflecting a portion of the incident light energy into space. The use of cool materials and green surfaces decreases solar gain of buildings and may also assist with moderation of the urban heat island effect (Mirzaei, 2016). Passive cooling eliminates or reduces the need for electric power-driven air conditioning, giving a range of financial and environmental benefits (Revel et al., 2014). Beyond energy savings and economic benefits in formal buildings, the coatings could provide thermal comfort to shack dwellers and occupants of low-cost non-air-conditioned buildings (Pisello, 2017).

Studies done in hot and arid climate settings indicate that passive cooling technologies may reduce the total energy consumption of a formal residential building by more than 20\% (Talieb, 2014; Algarni, 2018). Moreover, the maximum annual winter heating load penalty incurred by the cool roof is approximately $3 \%$ of the annual cooling load reduction, thus a negligible detriment (Algarni, 2018). The ability for cool coatings to reduce cooling energy loads may be an appropriate electric demand management strategy in places like South Africa, where load shedding is frequently applied. The use of cool coatings for energy management and the promotion of human comfort in buildings is a recognised and legislated requirement in some countries and city jurisdictions (Levinson et al., 2005; California Energy Commission, 2006). This is because of their demonstrated potential to enhance climate resilience and urban habitability (Gilbert et al., 2016).

Comparisons between different green cooling technologies and roof colours show that whitecoated roofs are three times more effective at cooling than vegetated roofs (Sproul et al., 2014). Furthermore, cool roofing materials demonstrate excellent weather resistance and may, therefore, enhance roof durability (Yanli et al., 2017). However, cooling degradation might happen over the lifecycle because of weathering and aging, hence the need for greater efforts in the development of cool materials that withstand the test of time (Tsoka et al., 2018).

Since the primary objective of cool coatings is to increase the cooling, more highly reflective materials are desirable and continue to be developed (Roman et al., 2016). However, the new generation of 'smart' cool materials must also promote wintertime comfort especially in thermally inefficient lowcost houses and informal settlements. Advances in nanotechnology have assisted in this regard, with the conception of highly reflective and thermally reversible thermochromic paints (Karlessi et al., 2009; Castaldo \& Pisello, (2019). These paints are designed to have a high reflectivity during the hot summer months and a high absorption rate in cold winter months, thereby helping to maintain a comfortable indoor ambience across seasons. Another mitigation technique in this domain is phasechange materials (PCM), which possesses high latent heat capacity and can be used as energy storage media and cooling in building envelopes (Chou et al., 2013; Kong et al., 2014). The PCM membranes absorb solar and infrared radiations and release a portion of the accrued thermal energy through convective and radiative processes into the atmosphere (Roman et al., 2016). Retro-reflective materials that reflect light back along the incident direction may achieve better overall cooling results than plain highly reflective materials (Yuan et al., 2015).

Although cool coatings seem to be beneficial for heat management in formal buildings (Miller et al., 2015), there is an evidence deficit of their efficacy in informal dwellings. It is this gap that motivated the present study, where comparative experimental work was carried out on indoor temperatures of two structurally identical informal structures, one cool-coated and the other untreated. The test structures were constructed to simulate typical shack 


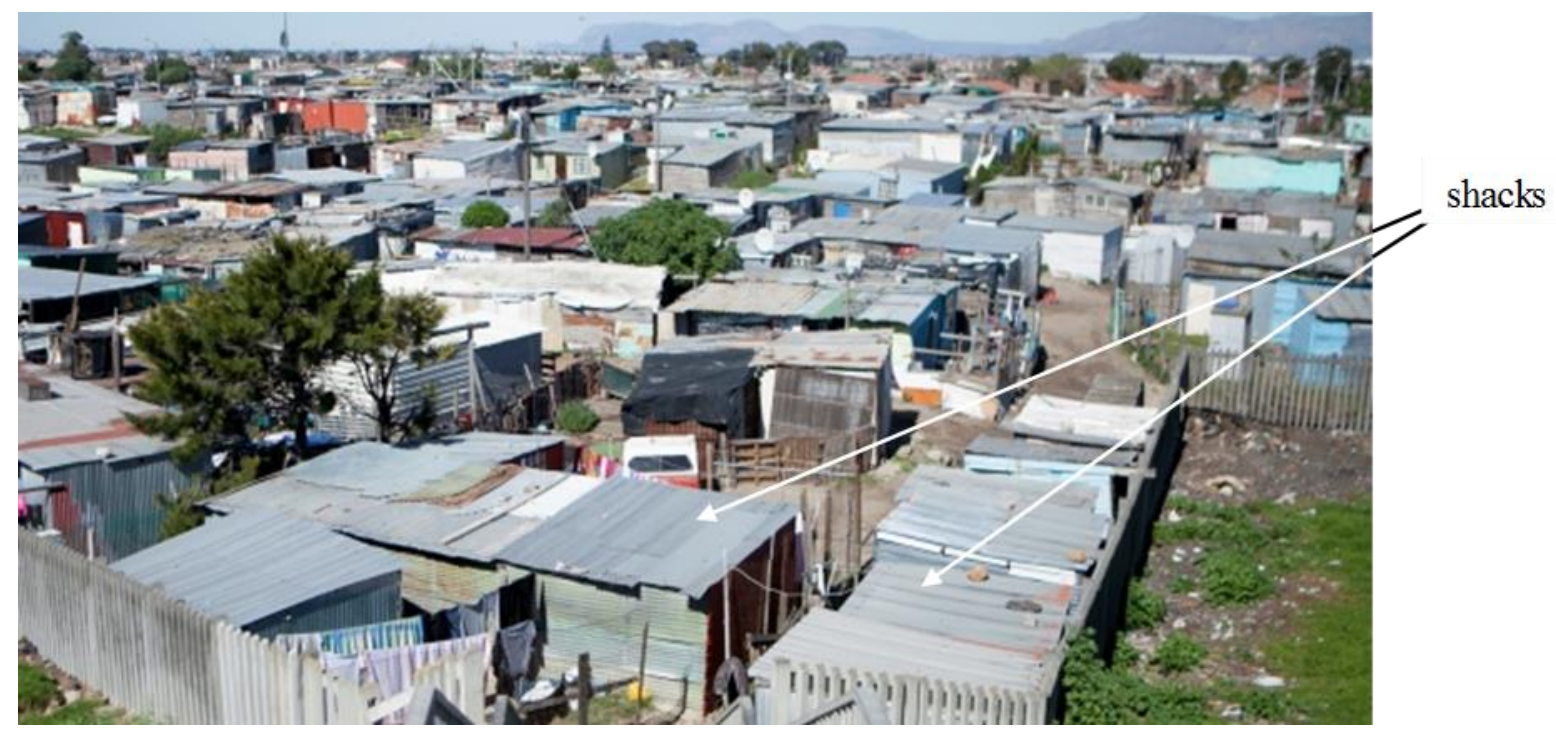

Figure 1: Image of an informal settlement in Cape Town, South Africa (Milne, 2017).

dwellings in the informal settlements that manifested around the larger cities of South Africa over the past three decades (Figure 1).

\section{Methodology \\ 2.1 Experimental site}

The experimental site was in Lenasia, Region G of the City of Johannesburg, Gauteng, South Africa (Latitude $-26.35^{\circ}$ and Longitude $27.85^{\circ}$; Google location: https://goo.gl/maps/onqK21n5tWC1BYky8); approximately $25 \mathrm{~km}$ south of the central business district (Figure 2). The site has an altitude of 1604 $\mathrm{m}$ above sea level. The local climate is classified as warm and temperate, with cool winters and warm summers. The temperature occasionally drops to -3 ${ }^{\circ} \mathrm{C}$ in winter and infrequently rises to above $40^{\circ} \mathrm{C}$ in spring, summer and autumn. Annual precipitation is $700 \mathrm{~mm}$, most of which occurs in summer and autumn (Climate-data, 2018).

\subsection{Equipment setup and data collection \\ Test structures}

A controlled experiment was set up to assess the efficacy of cool coatings in timber frame and galvanised iron sheet dwellings (Figure 3). Each structure measured $2.7 \mathrm{~m}$ (length), $2.2 \mathrm{~m}$ (front height) $2.0 \mathrm{~m}$ (rear height) and $2.0 \mathrm{~m}$ (width). The roof and outer walls of one of the structures were coated with cool coatings, leaving the other structure uncoated as the control. The structures had concrete floors but no ceilings or wall insulation. Both structures had one door and a curtained window facing north-east. The structures were naturally ventilated by air circulation through the small gaps between the roof and wall. The material used to construct the test structures, and the dimensions and orientation, were selected to mimic conditions in target community sites.

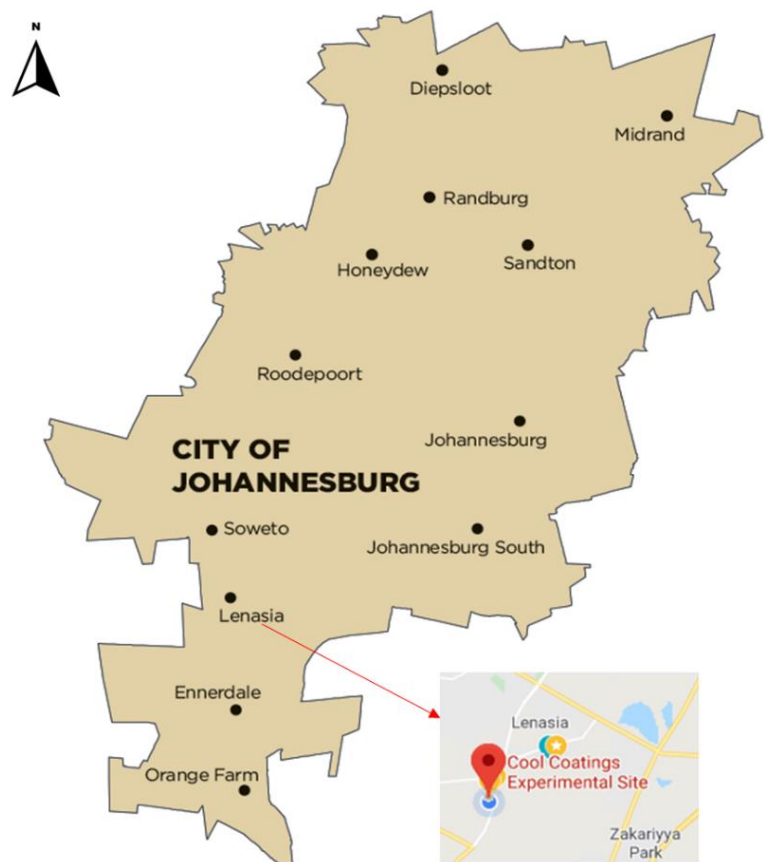

Figure 2: Location of study site in Lenasia, Johannesburg South, Gauteng, South Africa (Municipalities of South Africa, 2020).

\section{Cool coatings material and coating procedure}

The cool-coating material used in this study was white, with the following manufacturer-supplied performance limits: solar reflectance -0.84 , infrared emittance - 0.9, and solar reflectance index 106 (Cool Roof Rating Council, 2014). About 6.6 litres of the product were used to coat the roof and external walls of the test structure at a cost of ZAR 400. The coating was done in this manner:

- new galvanised iron sheets were cleaned and treated with two coats of water-based primer;

- two hours were allowed for drying; and 


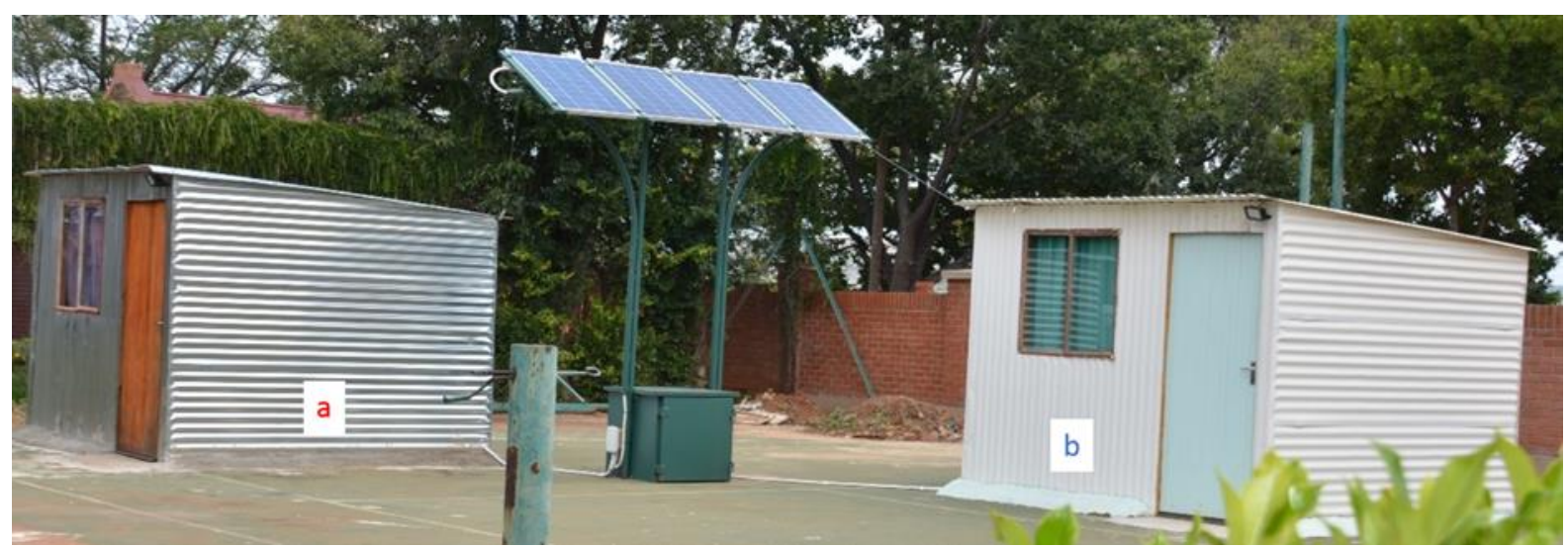

Figure 3: Experimental structures: a) uncoated (control) and b) coated.

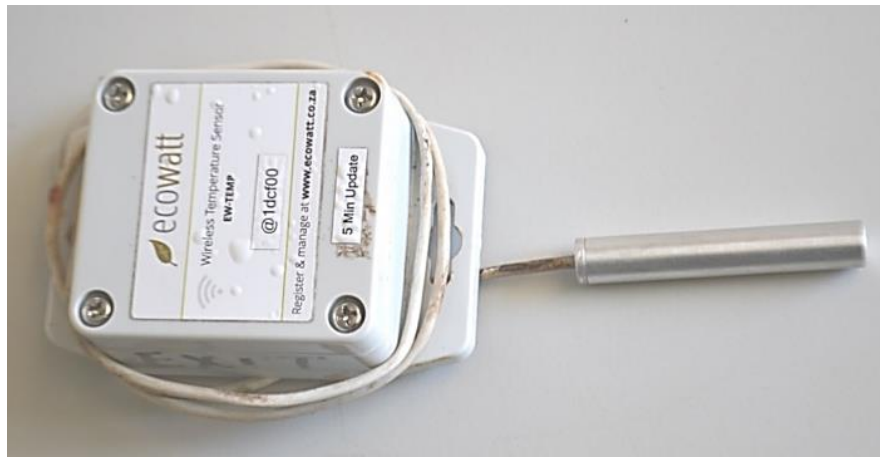

Figure 4: Temperature sensor.

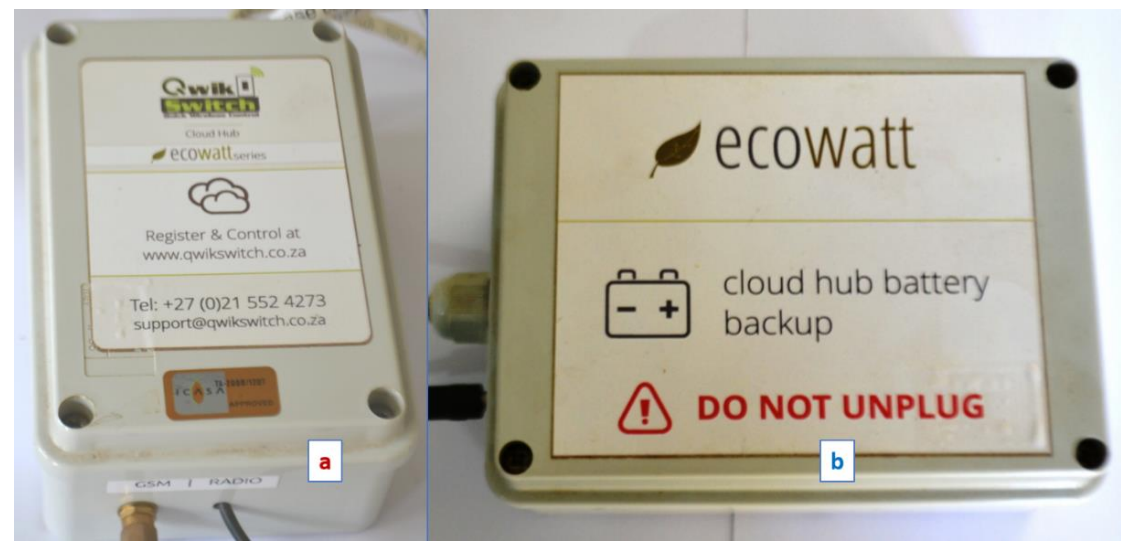

Figure 5: a) Cloud Hub $^{\text {TM }}$ data logger, b) Battery back-up.

- the primed surface was painted with the first cool coating and left to dry overnight before the application of the second and final coat.

\section{Temperature measurement equipment}

The equipment Included three wireless temperature sensors, a Cloud Hub data logger, and battery backup. The equipment was supplied by QwikSwitch ${ }^{\mathrm{TM}}$, a wireless automation and control solutions provider based in Cape Town. The equipment was purchased site-ready in mid-October 2016 and installed soon after. The battery-powered external temperature sensor consisted of a measurement probe attached to thermometer housing by a $2 \mathrm{~m}$ wire (Figure 4). Sensor measurement range was
$-20-90{ }^{\circ} \mathrm{C}$, designed to relay the temperature data to the data logger from about $30 \mathrm{~m}$ through walls and floors or a $100 \mathrm{~m}$ line-of-sight. Indoor temperatures of each test structure were continuously tracked with the temperature sensor suspended $500 \mathrm{~mm}$ at the centre of the room. A third sensor was set outside to measure ambient shade temperatures of the experimental site.

The Cloud Hub data logger (Figure 5) collected information from the temperature sensors, then formatted and transferred it to a web database. It typically used $30 \mathrm{MB}$ data per month, which was supplied through a data-enabled sim card. The Cloud Hub stayed connected to a power source, which was backed-up with a $12 \mathrm{~V}$ battery. Live readings of the logged data were accessed on the web 
dashboard that also contained recorded data in the form of graphs and PDF reports.

\subsection{Data collection procedures}

Once in place, the three temperature sensors were set and added to the Global System for Mobile communications (GSM) Cloud $\mathrm{Hub}^{\text {TM }}$ data logger through the web dashboard. Averaged readings were recorded every five minutes. The doors and windows of both structures were shut continuously except on rare occasions for checking the instruments or conducting a demonstration. Measurements were recorded from 16 November 2016 to 15 January 2018, a total of 408 days, excluding a period of 18 days from 21 October to 7 November 2017 , for which no data were available.

\subsection{Analytical methods}

The analysis procedure was a side-by-side comparison of indoor temperatures of the coated and uncoated structures. Temperature data were recorded in MS Excel sheets, sorted and exported to IBM SPSS Version 25 for analysis. Parameters of interest were the mean values, standard deviations and cooling effect. The summary-independent sam- ples t-test at 95\% confidence level was used to compare the statistical significance of mean temperature differences between the control and coated structures. The analysis covered the entire data set of 408 days, equivalent to $96 \%$ data recovery. Comparisons were then made for exceedances of the heat stroke critical value of $\geq 40{ }^{\circ} \mathrm{C}$.

\section{Results}

The maximum daily temperatures for the coated and control structures are plotted in Figure 6. The mean daily maximum temperature inside the test (coated) structure was $30.2{ }^{\circ} \mathrm{C}$, while that of the control structure (uncoated) was $34.5^{\circ} \mathrm{C}$, a cooling difference of $4.3^{\circ} \mathrm{C}$. The highest cooling effect in a day was $10{ }^{\circ} \mathrm{C}$. The same cooling trend was observed for the minimum daily temperatures, which were lower in the coated structure by an average of $2.2^{\circ} \mathrm{C}$.

Disaggregation of the data into the four traditional southern hemisphere seasons shows that the highest maximum and minimum mean temperatures were observed in summer. However, the largest cooling effects were observed in autumn (Table 1).

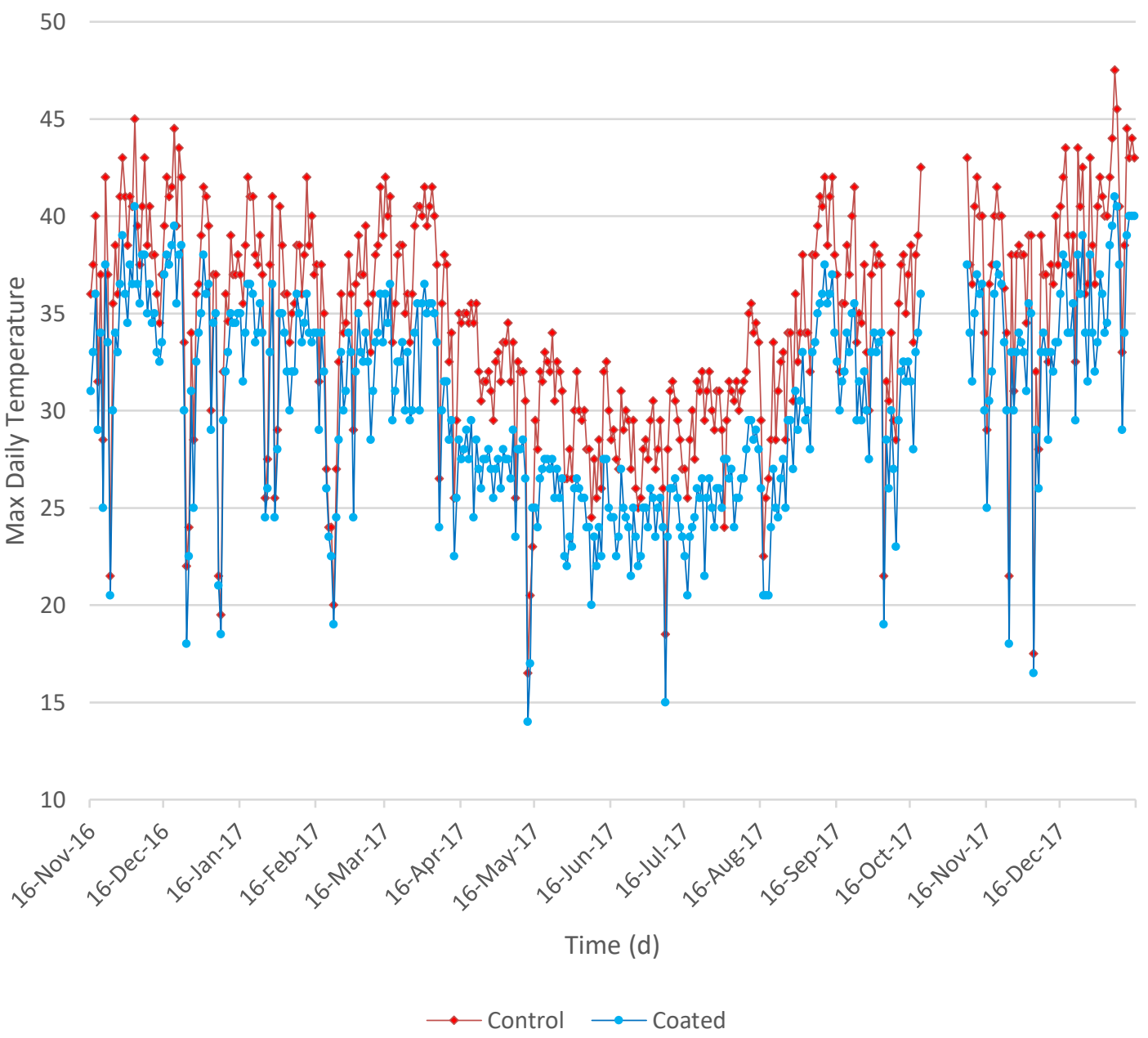

Figure 6: Daily maximum temperatures for coated and uncoated structures. 
Table 1. Temperature data for uncoated and coated structures by season.

\begin{tabular}{|c|c|c|c|c|c|c|c|c|}
\hline \multirow{3}{*}{ Experimental structures } & \multicolumn{8}{|c|}{ Mean seasonal max and min daily temperatures $\left({ }^{\circ} \mathrm{C}\right)$} \\
\hline & \multicolumn{2}{|c|}{$\begin{array}{c}\text { Summer (November- } \\
\text { February) }\end{array}$} & \multicolumn{2}{|c|}{$\begin{array}{c}\text { Autumn (March- } \\
\text { May) }\end{array}$} & \multicolumn{2}{|c|}{$\begin{array}{l}\text { Winter (June-Au- } \\
\text { gust) }\end{array}$} & \multicolumn{2}{|c|}{$\begin{array}{c}\text { Spring (September } \\
\text { October) }\end{array}$} \\
\hline & $\operatorname{Max}$ & Min & $\operatorname{Max}$ & Min & $\operatorname{Max}$ & Min & $\operatorname{Max}$ & Min \\
\hline Uncoated structure (US) & 36.9 & 17.6 & 33.9 & 13.0 & 29.5 & 7.6 & 36.5 & 12.9 \\
\hline Coated structure (CS) & 33.3 & 15.5 & 29.1 & 10.0 & 25.0 & 4.7 & 32.2 & 10.5 \\
\hline $\begin{array}{l}\triangle \text { Temp (US-CS) cooling } \\
\text { effect }\end{array}$ & 3.6 & 2.1 & 4.8 & 3.0 & 4.5 & 2.9 & 4.3 & 2.4 \\
\hline
\end{tabular}

Max. US $=36.9{ }^{\circ} \mathrm{C}$, Max. CS $=33.3^{\circ} \mathrm{C}$; Min. US $=7.6^{\circ} \mathrm{C}$, Min. $\mathrm{CS}=4.7^{\circ} \mathrm{C}$.

Table 2. Daily maximum temperatures and relative frequencies for test structures and ambient air.

\begin{tabular}{|c|c|c|c|c|c|c|}
\hline \multirow{3}{*}{$\begin{array}{c}\text { Daily max tempera- } \\
\text { tures }\left({ }^{\circ} \mathrm{C}\right)\end{array}$} & \multicolumn{6}{|c|}{ Frequency ( $n=408$ days) } \\
\hline & \multicolumn{2}{|c|}{ Control (Uncoated) } & \multicolumn{2}{|c|}{ Coated } & \multicolumn{2}{|c|}{ Ambient } \\
\hline & Days & $\%$ & Days & $\%$ & Days & $\%$ \\
\hline $10.0-14.5$ & 0 & 0.0 & 1 & 0.2 & 3 & 0.7 \\
\hline $15.0-19.5$ & 4 & 1.0 & 8 & 2.0 & 20 & 4.9 \\
\hline $20.0-24.5$ & 14 & 3.4 & 55 & 13.5 & 104 & 25.5 \\
\hline $25.0-29.5$ & 68 & 16.7 & 124 & 30.4 & 102 & 25.0 \\
\hline $30.0-34.5$ & 110 & 27.0 & 128 & 31.4 & 134 & 32.8 \\
\hline $35.0-39.5$ & 136 & 33.3 & 86 & 21.1 & 44 & 10.8 \\
\hline $40.0-44.5$ & 73 & 17.9 & 6 & 1.5 & 1 & 0.2 \\
\hline $45.0-50$ & 3 & 0.7 & 0 & 0.0 & 0 & 0.0 \\
\hline
\end{tabular}

It was tested whether the mean difference of the daily maximum and minimum temperatures of the test structures were significantly different. In this regard, the maximum daily temperature of the uncoated structure - mean $(\mathrm{M})=34.5$, standard deviation $(\mathrm{SD})=5.52$, number of days $(\mathrm{n})=408-$ was hypothesised to be greater than the maximum daily temperature of the coated structure $(\mathrm{M}=30.2, \mathrm{SD}=$ $5.20, \mathrm{n}=408)$. This difference was found to be statistically significant: $\mathrm{t}(814)=11.45, \mathrm{p}=0.00$ (2tailed). Equally, the mean minimum daily temperatures of the control structure $(M=13.7, S D=4.63, n$ $=408$ ) were significantly different from the mean minimum daily temperatures of the coated structure $(\mathrm{M}=11.2, \mathrm{SD}=5.14, \mathrm{n}=408), \mathrm{t}(814)=7.3, \mathrm{p}=$ $0.00)$. The results show that cool coatings were effective in reducing the indoor air temperatures of the coated structure.

Further analysis indicated that the maximum daily temperature in the control (uncoated) structure equalled or exceeded the critical heat stroke threshold of $40{ }^{\circ} \mathrm{C}$ (Hifumi et al., 2018) about 19\% of the time (76 days) compared with $1.5 \%$ ( 6 days) for the coated structure (Table 2 and Figure 7). This implies that the risk of heat stroke was 12 times greater in the uncoated structure than the coated one. Furthermore, the maximum daily temperatures of the control structure exceeded the peak heat stress threshold of $35^{\circ} \mathrm{C}$ (Sherwood \& Huber, 2010 ) about $50 \%$ of the time (203 days), compared with $18 \%$ (75 days) for the coated structure. By comparison, the maximum daily ambient temperature of the experimental site breeched the heat stress and heat stroke thresholds only $8 \%$ and $0.2 \%$ of the time, respectively. These results highlight the higher risk of exposure to heat illnesses indoors compared with outdoors and the inherent potential for cool coatings to ameliorate extreme heat exposures.

The diurnal temperature profiles for the two test structures are similar and largely influenced by the prevailing meteorological conditions (Figures 8 and 9). In both cases the temperatures are lowest in the early mornings, then rising sharply as the sun comes up and peaking around mid-afternoon. The steepest temperature rise is noticeable in winter days (Figure 9), especially in the control structure. In both summer and winter, the coated structure maintained comparatively cooler temperatures. 


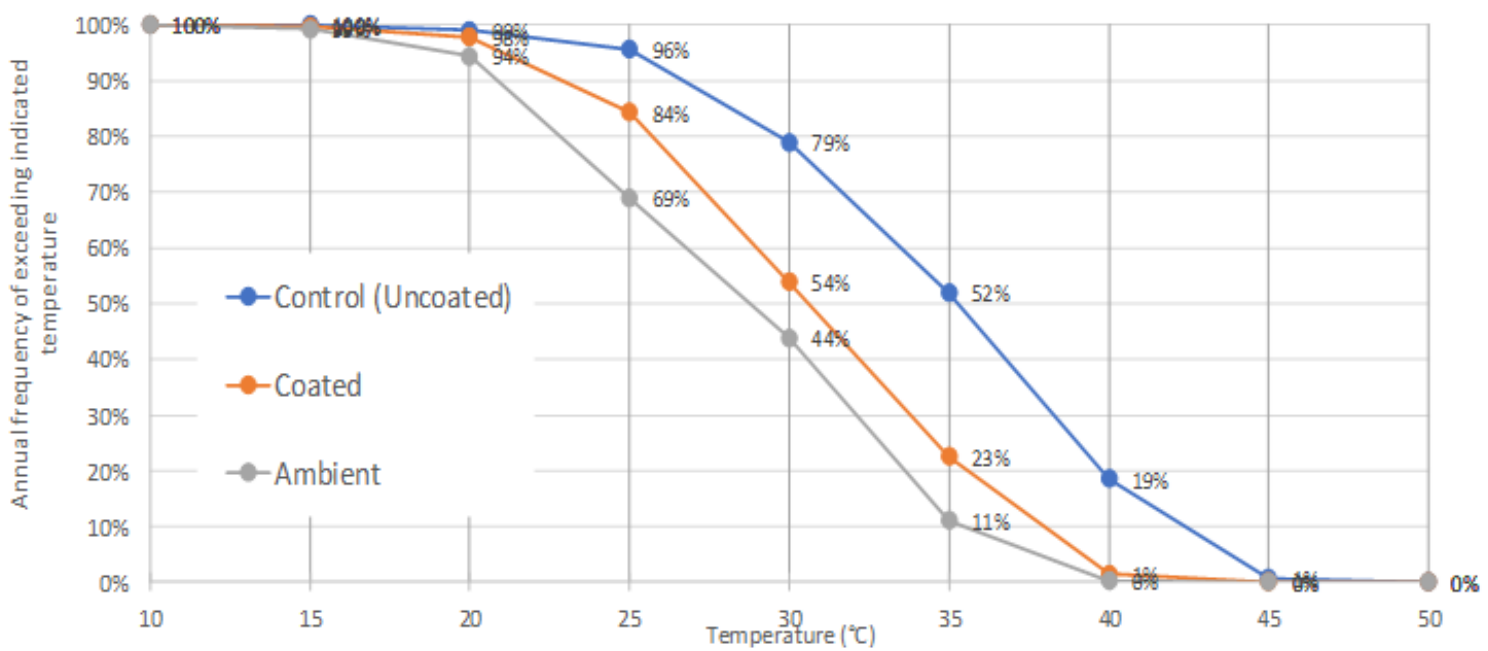

Figure 7: Cumulative annual frequencies of daily temperature exceedances above specified values.

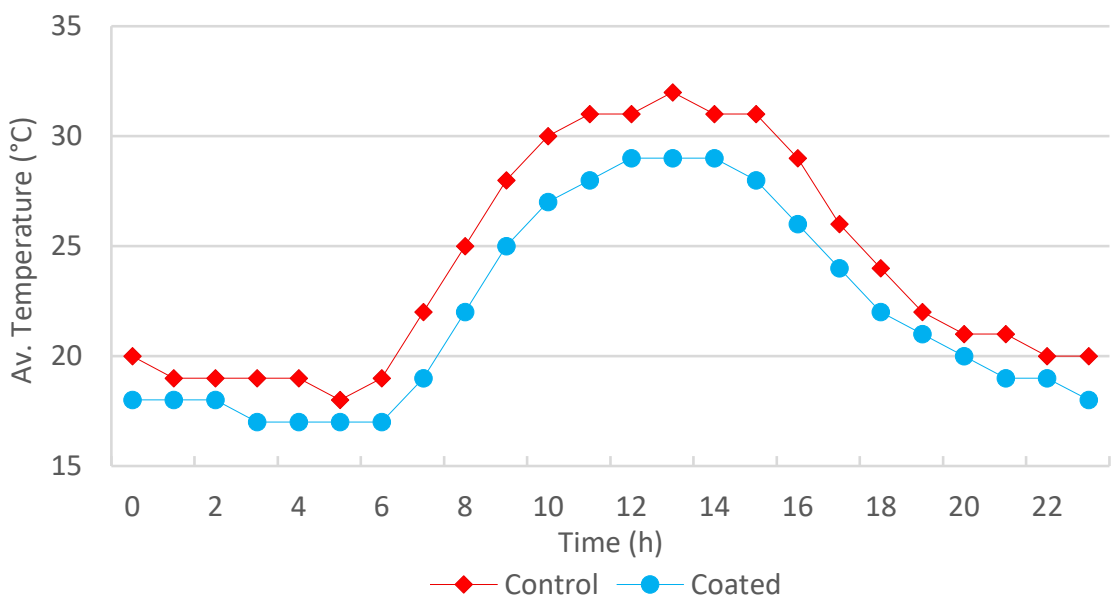

Figure 8. Diurnal temperature profile for selected summer month, February 2017.

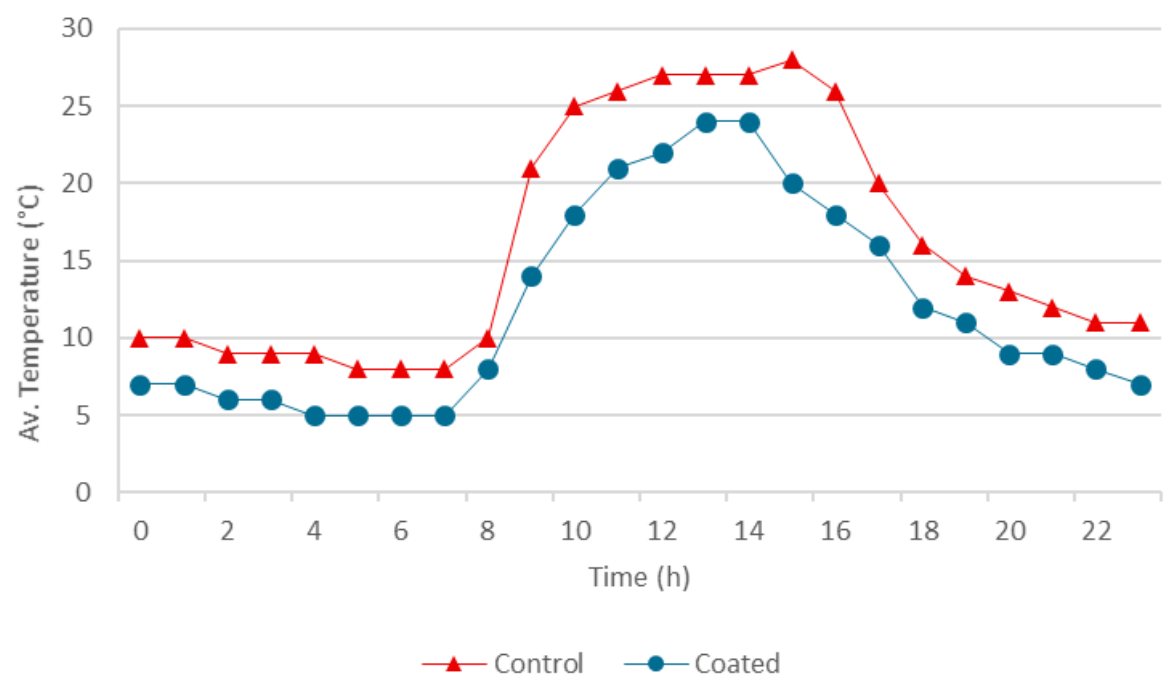

Figure 9: Diurnal temperatures profile for selected winter month, June 2017. 


\section{Discussion}

Increases in environmental heat are recognised as contributors to adverse health outcomes including psychological disorders, social distress, and fatalities, especially in energy-impoverished environments (Doherty \& Clayton, 2011; Mares \& Moffett, 2016). This study assessed the effectiveness of cool coatings as a possible technological response that may serve to mitigate the risks for negative health outcomes arising from extreme heat events in under-resourced settings. The results indicated that cool coatings are effective in maintaining significantly lower indoor temperatures. These findings are corroborated by similar empirical studies that focused on cool-coating applications to formal structures (Baniassadi et al., 2018). As such, the use of these coatings may be a solution to prevent or significantly reduce life-threatening impacts of extreme heat events in poor and energy-impoverished urban communities.

The study recognises that elevated indoor temperatures in informal houses may emanate from several factors, such as the types of building materials used, building orientation, confined spatial conditions and poor air circulation. Therefore, the use of cool coatings in low-income housing should be considered alongside interventions on safe, structurally appropriate and affordable housing for low-income households. Beyond individual houses, studies indicate that the use of the coatings in school classrooms promotes a better learning atmosphere and education outcomes, especially for vulnerable child populations that are dependent on natural ventilation and cooling (Sarbu \& Pacurar, 2015).

A fundamental limitation of the cool coatings is the possible winter discomfort that may arise from cooler indoor temperatures. This shortcoming could be mitigated with inexpensive countermeasures such as wall and ceiling insulation using cheaper available material, or possibly further design alterations to minimise the cooling effect of the coating below a specific ambient temperature range. This approach would be informed by recent advances in the production of thermally responsive materials that could automatically adapt to outdoor meteorological conditions of winter, summer and transitional seasons (Wang et al., 2019). Nevertheless, the current results have broad applicability in most areas of the African continent that are urbanising at a fast rate in a resource-constrained age (Swilling, 2015; Venables, 2018).

In the absence of protection offered by such interventions, health losses and social conflicts emanating from the exposure to elevated indoor heat will remain a challenge and may escalate (Chersich et al., 2019) alongside rising informality (Socio-Economic Rights Institute of South Africa, 2018) and higher seasonal temperatures (Lakhraj-Govender \& Grab, 2019). A case in point is Region G of the City of Johannesburg, the location of the current study, where unprecedented numbers of people have moved onto vacant land and erected thousands of metal shack dwellings, similar to the situation confronting most South African urban centres (Simelane, 2019). The challenges of dwelling in these basic structures are compounded by lack of access to formal energy carriers especially in environments that have limited green and shady spaces. There are further indications of a surge over time in protest violence and inter-personal and genderbased violence especially in marginalised spaces of urban life (Lau \& Seedat, 2017; De Juan \& Wegner, 2019). Although a complex set of factors are responsible for such interpersonal and social discord, interventions to promote thermal comfort despite the prevailing energy and structural impoverishments, may buffer against individual psychological stress and assist in the promotion of individual and community wellbeing and peace.

\section{Conclusions}

The results provide a proof of application effectiveness and offers interventionists and researchers working in partnership with housing authorities an empirical foundation to consider or advocate for the use of cool coatings for passive cooling. The intervention is easy to install and scale-up with unskilled labour. Besides reducing the direct threats of elevated heat, the intervention can assist in mitigating against heat-induced stress in under-resourced communities and in the prevention of related health and longer-term social concerns. It is recommended that governmental authorities and relevant role players invest in the production and assisted application of cool coatings in urban informal settlements. The interventions could be implemented in parallel with ongoing efforts focused on the design and implementation of low-cost, durable and thermally comfortable houses for poor communities. Public action should equally focus on imparting education on passive means of promoting thermal comfort in poor communities regardless of seasonal variations. These endeavours should ideally be supported through public-private and civil partnerships to accelerate delivery and spread potential economic gains. Ultimately, this could be a potential policy change to assist in expanding poor households' access to alternative and green energy resources. 


\section{Acknowledgements}

The work was funded by University of South Africa through the Ukuphepha Research Grant number S1400000111 to the Institute for Social and Health Sciences.

\section{Author roles}

D. Kimemia: Led research formulation, data collection, analyses and write-up.

A. Van Niekerk: Contributed in contextualisation, writeups, and text reviews.

H. Annegarn: Contributed in analytical techniques, interpretation of findings and text reviews.

M. Seedat: Participated in conceptualisation and text reviews.

\section{References}

Akbari, H., Mathews, D. 2012. Global cooling updates: Reflective roofs and pavements. Energy and Buildings, 55: 2-6.

Alam, M., Snjayan, J., Zou, P., Stewart, M., Wilson, J. 2016. Modelling the correlation between building energy ratings and heat-related mortality and morbidity. Sustainable Cities and Society, 22: 29-39. https://dx.doi.org/10.1016/j.scs.2016.01.006.

Algarni, S. 2018. Potential for cooling load reduction in residential buildings using cool roofs in the harsh climate of Saudi Arabia. Energy and Environment, 30(2): 235-253. https://doi.org/10.1177\%2F0958305X18787340.

Baniassadi, A., Heusinger, J., Sailor, J. 2018. Energy efficiency vs resiliency to extreme heat and power outages: The role of evolving building energy codes. Buildings and Environment, 139: 86-94. https://doi.org/10.1016/j.buildenv.2018.05.024.

California Energy Commission, 2006. 2005 Building energy efficiency standards for residential and non-residential buildings. No. CEC-400-2006-015. Available from https://ww2.energy.ca.gov/2006publications/CEC-400-2006015/CEC-400-2006-015.PDF, 10 February 2020.

Castaldo, V.L., Pisello, A.L. 2019. How urban mitigation technologies can contribute to decrease the cooling demand of buildings, in Santamouris, M. (ed.) Cooling energy solutions for buildings and cities. London: World Scientific: 345398.

Chersich, M.F., Swift, C.P., Edelstein, I., Breetzke, G., Scorgie, F., Schutte, F., and Wright, C. 2019. Violence in hot weather: Will climate change exacerbate rates of violence in South Africa? South African Medical Journal, 109(7): 447-449.

Chou, H., Chen, C., Nguyen, V. 2013. A new design of metal-sheet cool roof using PCM. Energy and Buildings, 57: 42-50.

Climate-data, 2018. Climate: Lenasia (Accessed on 4 July 2018); https://en.climate-data.org/location/27126/.

Cool Roof Rating Council, 2014. Rated products directory. Available from https://coolroofs.org/directory.

De Juan, A., Wegner, E. 2019. Social inequality, state-centred grievances and protest: Evidence from South Africa. Journal of Conflict Resolution, 63(1): 31-58.

Diamond, A.M. 2017. Keeping our cool: In defence of air conditioning. Available from https://digitalcommons.unomaha.edu/econrealestatefacpub/35.

Doherty, T.J., Clayton, S. 2011. The psychological impacts of global climate change. American Psychologist, 66(4): 265276.

Durnez, L., Mao, S., Roelants, P., Sochantha, T. and Coosemans, M. 2013. Outdoor malaria transmission in forested villages of Cambodia. Malaria Journal, 12: 329. http://www.malariajournal.com/content/12/1/329.

Garland, R.M., Matooane, M., Engelbrecht, F.A., Bopape, M.M., Landman, W., Naidoo, M., van der Merwe, J. and Wright, C. 2015. Regional projections of extreme apparent temperature days in Africa and the related potential risk to human health. International Journal of Environmental Research and Public Health, 12: 12577-12604. Doi:10.3390/ijerph121012577.

Gilbert, H., Mandel, B.H. and Levinson, R. 2016. Keeping California cool: Recent cool community developments. Energy and Buildings, 114: 20-26.

Habeeb, D., Vargo, J.and Stone, B. 2015. Rising heat wave trends in large US cities. Natural Hazards, 76: 1651. https://doi.org/10.1007/s11069-014-1563-z.

Harmon, K. 2010. How does a heat wave affect the human body? Scientific American (Accessed on 5 July 2018); https://www.scientificamerican.com/article/heat-wave-health/.

Hifumi, T., Kondo, Y., Shimizu, K. and Miyake, Y. 2018. Heat stroke. Journal of Intensive Care, 6, Article no. 30. https://doi.org/10.1186/s40560-018-0298-4.

Intergovernmental Panel on Climate Change. 2014. Climate Change 2014: Synthesis Report. Contribution of Working Groups I, II and III to the Fifth Assessment Report. Geneva, Switzerland: IPCC, 151 pp. Available from https://unfccc.int/topics/science/workstreams/cooperation-with-the-ipcc/the-fifth-assessment-report-of-the-ipcc, 10 February 2020.

Ishimine, P. Heat stroke in children (Accessed on 30 Oct. 18); https://www.uptodate.com/contents/heat-stroke-inchildren.

Karlessi, T., Santamouris, M., Apostolakis, K., Synnefa, A. and Livada, I. 2009. Development and testing of thermochromic coatings for buildings and urban structures. Solar Energy, 83(4): 538-551. 
Kong, X., Lu, S., Li, Y., Huang, J. and Liu, S. 2014. Numerical study on the thermal performance of building wall and roof incorporating phase change material panel for passive cooling application. Energy and Buildings, 81: 404-415.

Kovats, R. and Hajat, S. 2008. Heat stress and public health: A critical review. Annual Review of Public Health, 29: 4145.

Lakhraj-Govender, R. and Grab, S. 2019. Temperature trends for coastal and adjacent higher lying interior regions of KwaZulu-Natal, South Africa. Theoretical and Applied Climatology, 137: 373. https://doi.org/10.1007/s00704018-2602-6.

Lau, U. and Seedat, M. 2017. Structural violence and the struggle for recognition: Examining community narratives in a post-apartheid democracy. In: Seedat M., Suffla S. and Christie D, eds., Enlarging the scope of peace psychology. Cham, Switzerland: Springer.

Levinson, R., Akbari, H., Konopack, S. and Bretz, S. 2005. Inclusion of cool roofs in non-residential Title 24 prescriptive requirements. Energy Policy, 33: 151-170.

Luber, G. and McGeehin, M. 2008. Climate change and extreme heat events. American Journal of Preventive Medicine, 35(5): 429-435.

Lugo-Amador, N.M., Rothenhaus, T. and Moyer, P. 2004. Heat-related illness. Emergency Medicine Clinics of North America, 22: 315-327.

Madlener, R. and Sunak, Y. 2011. Impacts of urbanization on urban structures and energy demand: What can we learn for urban energy planning and urbanization management? Sustainable Cities and Society, 1: 45-53.

Madrigano, J., Ito, K., Johnson, S., Kinney, P. and Matte, T. 2015. A case-only study of vulnerability to heat wave-related mortality in New York City (2000-2011). Environmental Health Perspectives, 123(7): 672-678. https://dx.doi.org/10.1289/ehp.1408178.

Mares, D. and Moffett, K. 2016. Climate change and interpersonal violence: A 'global' estimate and regional inequities. Climate Change, 135(2): 297-310. https://doi.org/10.1007/s10584-015-1566-0.

Mastrucci, A., Byers, E., Pachauri, S. and Rao, N. 2019. Improving the SDG energy poverty targets: Residential cooling needs in the Global South. Energy and Buildings, 186(1): 405-415.

Mazdiyasni, O., AghaKouchak, A., Davis, S., Madadgar S., Mehran, A., Ragno, E., Sadegh, M., Sengupta, A., Ghosh, S., Dhanya, C. and Niknejad, M. 2017. Increasing probability of mortality during Indian heat waves. Science Advances, 3: $1-5$.

Miller, W., Crompton, G. Bell, J. 2015. Analysis of cool roof coatings for residential demand side management in tropical Australia. Energies, 8: 5303-5318.

Milne, N. 2017. The tale of two slums in South Africa, as residents seek to upgrade their lives. Available from https://www.huffingtonpost.co.uk/entry/the-tale-of-two-slums-in-south-africa-as-residents-seek-to-upgr, 06 February 2020.

Mirzaei, P.A. 2016. Recent challenges in modelling of urban heat island. Sustainable Cities and Society, 19: 200-206. https://doi.org/10.1016/j.scs.2015.04.001.

Monroe, A., Asamoah, O., Lam, Y., Koenker, H., Psychas, P., Lynch, M., Ricotta, E., Hornston, S., Berman, A. and Harvey, S. 2015. Outdoor-sleeping and other night-time activities in northern Ghana: implications for residual transmission and malaria prevention. Malaria Journal, 14: 35. DOI 10.1186/s12936-015-0543-4.

Municipalities of South Africa, 2020. City of Johannesburg Metropolitan Municipality (JHB). Available from https://municipalities.co.za/map/2/city-of-johannesburg-metropolitan-municipality, 29 January 2020.

Muringathuparambila, R., Musango, J., Brent, A. and Currie, P. 2017. Developing building typologies to examine energy efficiency in representative low-cost buildings in Cape Town townships. Sustainable Cities and Society, 33: 1-7.

Pisello, L.A. 2017. State of the art on the development of cool coatings for buildings and cities. Solar Energy, 144: 660680.

Ranson, M. 2014. Crime, weather, and climate change. Journal of Environmental Economics and Management, 67(3): 274-302.

Revel, G.M., Martarelli, M., Emiliani, M., Gozalbo, A., Orts, M., Bengochea, M., Delgado, L., Gaki, A., Katsiapi, A., Taxiarchou, M., Arabatzis, I., Fasaki, I. and Hermanns, S. 2014. Cool products for building envelope - Part I: Development and lab scale testing. Solar Energy, 105: 770-779.

Riley, K., Wilhalme, H., Delp, L. and Eisenman DP. 2018. Mortality and morbidity during extreme heat events and prevalence of outdoor work: An analysis of community-level data from Los Angeles County, California. International Journal Environmental Research and Public Health, 15(4): 580-592.

Roman, K., O'Brien, T., Alvery, J. and Woo, 0. 2016. Simulating the effects of cool roof and PCM (phase change materials) based roof to mitigate UHI (urban heat island) in prominent US cities. Energy, 96: 103-117. https://doi.org/10.1016/j.energy.2015.11.082.

Sarbu, I. and Pacurar, C. 2015. Experimental and numerical research to assess indoor environment quality and schoolwork performance in university classrooms. Building and Environment, 93, 14-154.

Satterthwaite, D. 2011. How urban societies can adapt to resource shortage and climate change. Philosophical Transactions of the Royal Society, 369: 1762-1783. https://royalsocietypublishing.org/doi/10.1098/rsta.2010.0350. 
Sherwood, C. and Huber M. 2010. An adaptability limit to climate change due to heat stress. Proceedings of the National Academy of Sciences of the United States of America (PNAS), 107(21): 9552-9555. www.pnas.org/cgi/doi/10.1073/pnas.0913352107.

Simelane, BC. 2019. Joburg South land grabs: 'We will go to war' say residents. Daily Maverick, https://www.dailymaverick.co.za/article/2019-07-21-joburg-south-land-grabs-we-will-go-to-war-say-residents/.

Simoes, SG., Gregorio, V. and Seixas J. 2016. Mapping fuel poverty in Portugal. Energy Procedia, 106: 155-165.

Socio-Economic Rights Institute of South Africa. 2018. Informal settlements and human rights in South Africa. Available from https://www.ohchr.org/Documents/Issues/Housing/InformalSettlements/SERI.pdf, 29 November 2019.

Sproul, J., Wan, M., Mandel, B. and Rosenfield A.H. 2014. Economic comparison of white, green, and black flat roofs in the United States. Energy and Buildings, 71: 20-27. https://dx.doi.org/10.1016/j.enbuild.2013.11.058.

StatsSA, 2018. General household survey: statistical release P0318. Available from http://www.statssa.gov.za/publications/P0318/P03182018.pdf.

Swilling, M. 2015. Towards sustainable urban infrastructures for the urban Anthropocene. In: Allen, A., Lampis, A and Swilling, M., eds., Untamed urbanisms, 1st ed. London: Routledge.

Talieb, H.M. 2014. Using passive cooling strategies to improve thermal performance and reduce energy consumption of residential buildings in U.A.E. buildings. Frontiers of Architectural Research, 3: 154-165.

Thomson, H., Simcock, N., Bouzarovski, S. and Petrova, S. 2019. Energy poverty and indoor cooling: An overlooked issue in Europe. Energy and Buildings, 196: 21-29. https://doi.org/10.1016/j.enbuild.2019.05.014.

Tsoka, S., Theodosiou, T., Tsikaloudaki, K. and Flourentzou, F. 2018. Modelling the performance of cool pavements and the effect of their aging on outdoor surface and air temperatures. Sustainable Cities and Society, 42: 276-288.

Turok, I. and Borel-Saladin, J. 2016. Backyard shacks, informality and the urban housing crisis in South Africa: Stopgap or prototype solution? Housing Studies, 31(4): 384-409. DOI: 10.1080/02673037.2015.1091921.

UN-Habitat, 2018. Sustainable cities and communities. Available from https://unhabitat.org/wp-content/uploads/2018/07/UN-Habitat-Brochure.pdf (Accessed 12 Sept 2019).

United Nations, 2019. SDG knowledge platform - progress of goal 7 in 2019. Available from https://sustainabledevelopment.un.org/sdg7, 29 October 19.

Urge-Vorsatz, D. and Herrero, S. 2012. Building synergies between climate change mitigation and energy poverty alleviation. Energy Policy, 49: 83-90. https://doi.org/10.1016/j.enpol.2011.11.093.

Venables, AJ. 2018. Urbanisation in developing economies: Building cities that work. Economic Research Southern Africa, 5(1), 91-100.

Wang, C., Zhu, Y. and Guo, X. 2019. Thermally responsive coating on building heating and cooling energy efficiency and indoor comfort improvement. Applied Energy, 253(1): 113506. https://doi.org/10.1016/j.apenergy.2019.113506.

WHO. 2018. Climate change and health: Key facts (Accessed 4 July 4, 2018); http://www.who.int/news-room/factsheets/detail/climate-change-and-health.

Wright, CY., Kapwata, T. and Wernecke, B. 2019. Gathering the evidence and identifying opportunities for future research in climate, heat and health in South Africa: The role of the South African Medical Research Council. South African Medical Journal, 109(11b): 20-24.

Yanli, Q., Xiang, B. and Zang J. 2017. Effect of titanium dioxide (TiO2) with different crystal forms and surface modifications on cooling property and surface wettability of cool roofing materials. Solar Energy Materials and Solar Cells, 172: 34-43.

Yuan, J., Farnham, C. and Emura K. 2015. A study on the accuracy of determining the retro-reflectance of retro-reflective material by heat balance. Solar Energy, 122: 419-428. 